\title{
ORGANIZACJA WOJSKOWA PELOPONEZU WEDŁUG JERZEGO GEMISTOSA PLETHONA
}

Postulaty nowej organizacji wojskowej państwa, które wysuwał Jerzy Gemistos Plethon (ok. 1355/1360 - ok. 1452), to głos nawołujący do radykalnych zmian w trudnych czasach. Ten radykalizm, charakteryzujący całość propozycji ustrojowych wysuwanych przez Plethona, był różnie interpretowany. François Masai (19 X 1909 - 12 IX 1979) przekonuje, że „Powinniśmy wyobrazić sobie Plethona mocno przejętego losem ojczyzny i z drugiej strony rozważającego klasyków, szczególnie Platona"1. Według francuskiego badacza filozof uważał, że „Z całej siły należy więc dążyć do odrodzenia Grecji, przywrócenia jej instytucji Sparty, myśli Platona a nawet - jak twierdził w swych pismach ezoterycznych - religii, jej wspaniałych kosmologicznych mitów"2. Nowsze badania przynoszą bardziej urozmaicone wnioski: ,[...] w jego [Plethona] propozycjach pobrzmiewają koncepcje platońskie, nieco tradycyjnej ideologii bizantyńskiej, trochę bodźców pochodzących ze współczesnych mu warunków ekonomicznych, wzbogaconych o nowatorską syntezę, stanowiącą oryginalną część jego dzieła"’.

Koncepcja Plethona była interpretowana jako nawoływanie do powrotu do helleńskich korzeni kultury bizantyńskiej, ale też jako wezwanie do reform bizantyńskich instytucji lub wręcz jako propozycja przeszczepienia elementów systemu, któremu swoją potęgę zawdzięczał główny rywal wschodniego Cesarstwa Rzymskiego: imperium osmańskie ${ }^{4}$. Celem niniejszego artykułu jest wykazanie, że te interpretacje da się pogodzić. Po pierwsze, pisma Plethona można odczytywać na różnych poziomach: na poziomie tożsamości kulturowej i na poziomie swoiście pojętego pragmatyzmu. Nawrót do helleńskiej tradycji niekoniecznie musi oznaczać zerwanie z bizantyńskimi instytucjami. Po drugie, Plethon wyrażał swoje postulaty na dość wysokim poziomie ogólności.

* Dr Jacek Raszewski - adiunkt w Pracowni Studiów Helleńskich na Wydziale „Artes Liberales" Uniwersytetu Warszawskiego; e-mail: gemistos@gmail.com.

${ }^{1}$ F. Masai, Pléthon et le platonisme de Mistra, Paris 1956, 68, tłum. własne.

${ }^{2}$ Tamże, s. 96, tłum. własne.

${ }^{3}$ A.E. Laiou, Economic Though and Ideology, w: The Economic History of Byzantium. From the Seventh through the Fifteenth Century, ed. A.E. Laiou, Washington 2007, 113, tłum. własne.

${ }^{4}$ Por. N. Necipoğlu, Byzantium Between the Ottomans and the Latins: Politics and Society in the Late Empire, Cambridge 2009, 274-276. 
Rozwiązania przez niego zaproponowane mogły łączyć inspiracje bizantyńskie i osmańskie, a sam autor niekoniecznie musiał widzieć tu sprzeczność.

Stawiamy więc pytanie o inspiracje rozwiązań, które Plethon proponował w zakresie organizacji wojskowej państwa. Naszym celem jest uporządkowanie opinii pojawiających się w literaturze przedmiotu oraz rozwinięcie niektórych wątków. Jako że bizantyńskie inspiracje Plethona zostały dość skrupulatnie przeanalizowane gdzie indziej ${ }^{5}$, w niniejszym artykule przedstawię tylko zwięzłe podsumowanie tego zagadnienia, aby czytelnik dysponował jak najpełniejszym obrazem. Wbrew pierwszeństwu chronologicznemu, proponuję przyjrzenie się najpierw współczesnym Plethonowi możliwym źródłom inspiracji.

1. Bizantyński reformator. Swoje koncepcje reformy państwa Plethon przedstawia $\mathrm{w}$ trzech pismach $^{6}$ adresowanych kolejno do: cesarza Manuela II Paleologa (27 VI 1350 - 21 VII 1425; cesarz od 16 II 1391)7 (krótko przed rokiem 1415), następnie do cesarskiego syna, despoty Peloponezu, Teodora II (ok. 1396 - 21 VI 1448) (pod koniec 1417 r.) oraz znów do Manuela II (rok 1418) ${ }^{9}$. Rozwinięcie lub przynajmniej nawiązanie do tych koncepcji najprawdopodobniej znajdowało się w Spisie praw - dziele, którego Plethon nie opublikował za życia. Po śmierci filozofa rękopis został w dużej części zniszczony przez pierwszego patriarchę Konstantynopola po 1453 r., Jerzego Scholariosa (1405-1473; patriarcha Konstantynopola w latach 1454-1464) ${ }^{10}$. Zachowany tekst nie pomaga $\mathrm{w}$ rekonstrukcji koncepcji reorganizacji systemu obrony Peloponezu.

Mamy więc do czynienia z trzema krótkimi utworami adresowanymi do bizantyńskich władców w czasach trudnych zarówno dla Konstantynopola jak

${ }^{5}$ Por. J. Raszewski, Jerzy Gemistos Plethon i jego helleńskie państwo, Warszawa 2010, 112-173 (niepublikowana rozprawa doktorska). Tam też szczegółowy opis reorganizacji wojskowej Peloponezu i bibliografia.

${ }^{6}$ Por. D.A. Zakythinos, Les Despotat grec de Morée. Histoire politique, t. 1, London 1932

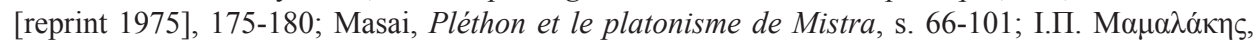

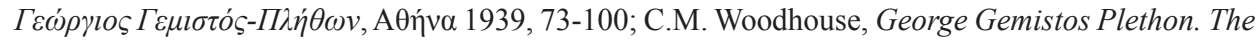
Last of Hellenes, Oxford 1986, 79-118; M.C. Bartusis, The Late Byzantine Army. Arms and Society, 1204-1453, Philadelphia 1992, 217-221; N. Siniossoglou, Radical Platonism in Byzantium. Illumination and Utopia in Gemistot Plethon, Cambridge 2011, 327-347.

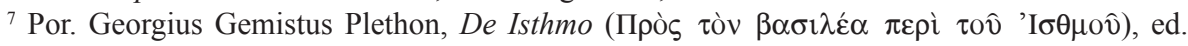

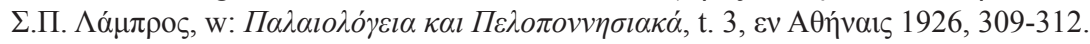

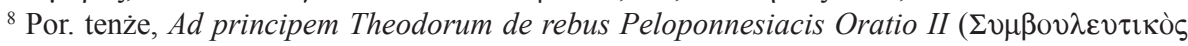

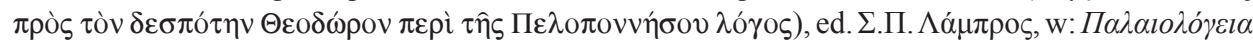

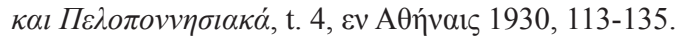

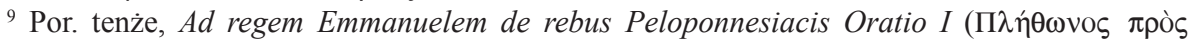

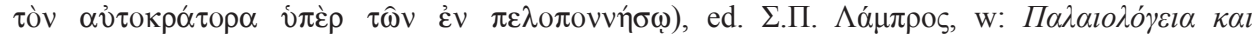

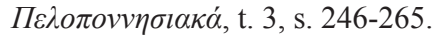

${ }^{10}$ Por. Woodhouse, George Gemistos Plethon, s. 357-359; J. Monfasani, Pletho's Date of Death and the Burning of his „Laws”, ByZ 98 (2005) 459-463, spec. 462-463. 
i dla Despotatu Morei. Nadawca nie jest dla adresatów osobą nieznaną. Przebywa na dworze w Mistrze, ponieważ został wygnany z Konstantynopola. Powodem tego wygnania miała być treść nauczania, jakie oferował w bizantyńskiej stolicy. Na uwagę zasługuje fakt, że nie został on relegowany poza granice państwa, a do ważnego dla Paleologów ośrodka, jakim była stolica Peloponezu. Do władców pisze więc filozof znany z ekscentrycznych poglądów, ale ceniony na tyle, że dynastia panująca jest skłonna rozpostrzeć nad nim swego rodzaju parasol ochronny.

Rdzeń swojej koncepcji Plethon zawarł w drugim, często cytowanym, piśmie adresowanym do Manuela:

„Uważam więc, że najpierw to trzeba naprawić, aby tych samych [ludzi] jednocześnie nie zaciaggać do wojska i nie obciążać daninami, lecz wpierw wszystkich Peloponezyjczyków podzielić na dwie [grupy], osobno zobowiązanych do służby wojskowej, osobno tych, którzy będą obciążeni daninami, i do obu z tych [grup przydzielić], każdego [według tego] raczej, [do jakiej] zdaje się być urodzony; tych, którzy świadczą służbę wojskową, należy zwolnić ze wszystkich danin i dostarczyć tego, co potrzebne do wyżywienia się, wpłacających daniny natomiast należy zwolnić ze wszelkiej służby wojskowej; nie powinno być tedy oczywiście dłużej opłat ściaganych po trosze, często i przez wiele osób, ani danin w gotówce; ściaganie opłat w tej postaci jest bowiem najuciążliwsze dla jednych i drugich: i dla składających daniny, i je inkasujących, raczej należy wnosić daninę jednego rodzaju, i to w naturze, pobieraną przez jednego [poborce] od każdego podatnika, tego rodzaju i w takiej wysokości, która zarazem będzie sprawiedliwa, i która wystarczy na potrzeby [państwa], a dla uiszczających, aby była jak najłatwiejsza do zniesienia" "1.

Według filozofa konieczne jest więc ścisłe rozgraniczenie dwu grup ludności: jednej zajmującej się obroną państwa i drugiej zajmującej się zaopatrzeniem ludności w żywność. Tylko tej drugiej grupy (,warstwy wytwórczej”,

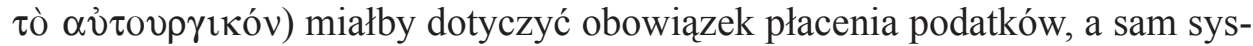
tem podatkowy powinien zostać uproszczony ${ }^{12}$. Gdzie indziej obraz jest uzupełniony o trzecią grupę, składającą się na docelowe społeczeństwo: „warstwę

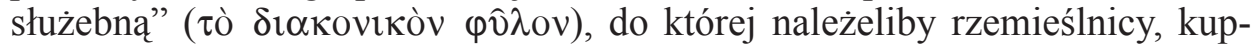
cy, handlarze i pracownicy fizyczni ${ }^{13}$. Z punktu widzenia ludności wojskowej reforma Plethona oznaczałaby ścisłe zdefiniowanie obowiązków grupy parającej się rzemiosłem wojennym $\mathrm{w}$ realiach społeczeństwa podzielonego na

${ }^{11}$ Georgius Gemistus Plethon, Ad regem Emmanuelem de rebus Peloponnesiacis Oratio I, ed.

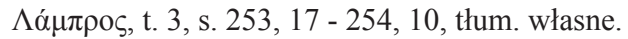

${ }^{12}$ Por. A.E. Laiou, The Agrarian Economy, Thirteenth-Fifteenth Centuries, w: The Economic History of Byzantium, s. 311-375, spec. 337-338.

${ }^{13}$ Por. Georgius Gemistus Plethon, Ad principem Theodorum de rebus Peloponnesiacis Oratio

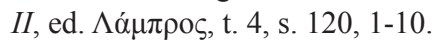


trzy grupy zawodowe. Zostałaby ona pozbawiona obowiązku podatkowego ${ }^{14}$. Utrzymywana byłaby z podatków płaconych przez rolników ${ }^{15}$.

Na uwagę zasługuje fakt, że mimo tak pieczołowitego podziału obowiązków, żołnierze zostali zaliczeni do grupy, której rola wykracza poza ściśle pojętą działalność militarną. Zaliczają się do niej, oprócz dowódców wojennych, również dygnitarze cywilni, sędziowie, a jej najczcigodniejszym członkiem jest sam cesarz ${ }^{16}$. Tak sformowaną grupę nazywa Plethon „warstwą rządzącą”

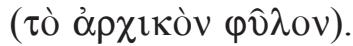

Te dwie cechy: postulat istnienia cywilno-wojskowej elity oraz ścisłe powiązanie dochodów tejże elity z opłatami wnoszonymi przez rolników skłoniły badaczy do poszukiwania inspiracji Plethona w bizantyńskiej instytucji prono $^{17}$. Jej funkcjonowanie oparte było na przydzieleniu beneficjentom prawa do czerpania dochodów z określonego terenu przeznaczonego pod uprawę czy innego rodzaju działalność rolniczą czy hodowlaną. Formalnie prawo do pobierania tych opłat (czynszów, podatków oraz innego rodzaju danin), było cedowane przez państwo (lub innego właściciela ziemi) na rzecz jednostki lub ciała kolektywnego (np. klasztoru). Nadania państwowe były często związane ze służbą wojskową beneficjenta. Początkowo były to więc nadania warunkowe i ograniczone $\mathrm{w}$ czasie $^{18}$. W ostatnich wiekach istnienia Bizancjum spotykamy jednak i takie wypadki, gdzie przywileje pronojarów są o wiele szersze, włączając $w$ to dziedziczenie. Przykładem beneficjenta takich nadań jest sam Plethon ${ }^{19}$. Model proponowany przez niego zakładałby powiązanie na powrót instytucji pronoi z obowiązkiem służby na rzecz państwa. Zauważyć trzeba jednak, że status majątkowy pronojarów, z których każdy utrzymywany byłby przez maksymalnie kilku chłopów, byłby radykalnie niższy od statusu nawet najuboższych beneficjentów tego przywileju w czasach Plethona ${ }^{20}$. Jednocześnie dla zapewnienia dochodów większej liczbie żołnierzy Plethon najprawdopodobniej brał pod uwagę nacjonalizację majątków klasztornych.

${ }^{14}$ Por. tamże, ed. $\Lambda$ $\alpha \mu \pi \rho \varsigma_{\text {, t. }}$ 4, 123, 22 - 124, 1.

${ }^{15}$ Por. tenże, Ad regem Emmanuelem de rebus Peloponnesiacis Oratio I, ed. $\Lambda \alpha ́ \mu \pi \rho \circ \varsigma$, t. 3, s. $257,16-18$.

${ }^{16}$ Por. tenże, Ad principem Theodorum de rebus Peloponnesiacis Oratio II, ed. $\Lambda \alpha ́ \mu \pi \rho \circ \varsigma$, t. 4, s. $120,12-13$.

${ }^{17}$ Por. M.C. Bartusis, The Cost of Late Byzantine Warfare and Defense, ByF 16 (1991) 75-89, spec. 88-89.

${ }^{18}$ Por. A. Kazhdan, Pronoia: The History of a Scholarly Discussion, „Mediterranean Historical Review" 10 (1995) 133-163; P. Charanis, The Monastic Properties and the State in the Byzantine Empire, DOP 4 (1948) 51-118; tenże, On the Social Structure and Economic Organization of the Byzantine Empire in the Thirteenth Century and later, „Byzantinoslavica” 12 (1951) 94-153, spec. 108-118.

${ }^{19}$ Por. Bartusis, The Late Byzantine Army, s. 289-290.

${ }^{20}$ Por. Raszewski, Jerzy Gemistos Plethon, s. 161-164. 
2. Między Bizancjum a imperium osmańskim. Odnosząc się do projektu reform Jerzego Gemistosa Plethona Nevra Necipoğlu wyraziła następującą opinię: ,[...] należy zwrócić uwagę na uderzające podobieństwo z ówczesną osmańską praktyka, dotycząca podziału ludności na żołnierzy i podatników [...]. Stosując dualistyczny system, Osmanie dzielili ludność na klasę wojskową, która nie angażowała się w produkcję i nie płaciła żadnych podatków (askerî), i klasę producentów, którzy jednocześnie byli podatnikami (reya)"21.

Autorka podkreśla przejawiający się w zobowiązaniach fiskalnych (lub ich braku) kontrast pomiędzy ludnością zajmującą się działalnością wojskową i ludnością zaangażowaną $\mathrm{w}$ produkcję dóbr konsumpcyjnych ${ }^{22}$. Zważywszy na temat niniejszego artykułu, kuszącym wydaje się bliższe spojrzenie na jedną $\mathrm{z}$ grup powstałych $\mathrm{w}$ wyniku tak nakreślonego podziału, na Plethońskich strażników i osmańskich askerî. Czy instytucje regulujące funkcjonowanie osmańskich wojowników wykazują podobieństwo do tych postulowanych przez peloponeskiego filozofa?

Interesujące w tym zakresie wydają się wydarzenia, które miały miejsce niemal trzydzieści lat po śmierci Plethona. Wtedy to zdobywca Konstantynopola, Mehmed II (30 III 1432 - 3 V 1481; sułtan w latach 1444-1446 i 14511481), zdecydował o reformie stosunków fiskalnych imperium. Reforma polegała na likwidacji nadań typu mülk i vakıf. Terytoria objęte reformą miały być włączone do systemu timar. Reforma nie udała się z powodu ogromnego oporu ze strony samych zainteresowanych: właścicieli likwidowanych nadań ${ }^{23}$.

Co w praktyce oznaczała taka reforma? Beneficjentami nadań typu mülk były osoby, które wyróżniły się szczególnymi zasługami dla państwa. Otrzymywały one prawo pobierania podatków i czerpania innego rodzaju dochodów z określonych terytoriów oraz do wpływania na stosowany tam model produkcji. Ziemie objęte tego typu nadaniami były w dużym stopniu wyjęte spod jurysdykcji państwowej. Tymi prawami właściciel nadania mógł dość swobodnie dysponować. Mógł przekazywać je również w spadku ${ }^{24}$. System timar ograniczał $\mathrm{w}$ dużym stopniu te przywileje. Tu również beneficjent mógł czerpać dochody z przydzielonych mu terenów, państwo przyznawało mu prawo do pobierania części należności podatkowych. Nie miał jednak żadnych gwarancji dotyczących czasu trwania tych praw. Było to nadanie warunkowe, którego podstawą była lojalność wobec państwa. Nadanie takie mogło zostać

${ }^{21}$ Necipoğlu, Byzantium Between the Ottomans and the Latins, s. 275, thum. własne.

${ }^{22}$ Nieobecność części ludności zajmującej się rzemiosłem wojennym w rejestrach podatkowych sprawia kłopot demografom, próbującym szacować wielkość populacji imperium osmańskiego. Por. L. Erder, The Measurment of Preindustrial Population Changes: The Ottoman Empire from the $15^{\text {th }}$ to the $17^{\text {th }}$ Century, „Middle Eastern Studies” 11 (1975) fasc. 3, 284-301.

${ }^{23}$ Por. O. Özel, Limits of the Almighty: Mehmed II's ,LLand Reform” Revisited, „,ournal of the Economic and Social History of Orient" 42 (1999) fasc. 2, 226-246.

${ }^{24}$ Por. H. İnalc1k, An Economic and Social History of the Ottoman Empire, 1300-1914, Cambridge 1994, 120-126. 
odebrane i przekazane innemu beneficjentowi ${ }^{25}$. Co ważne, zarówno timarioci, jak i beneficjenci nadań typu mülk nie byli właścicielami przyznanych im terenów, ani dochodów, które te tereny przynosiły ${ }^{26}$, choć w wypadku drugiej formy użytkowania prawa beneficjenta były daleko większe.

Przytaczając przykład Mehmeda II nie staramy się sugerować, że istniała zależność pomiędzy jego reformą a programem nakreślonym pół wieku wcześniej przez Plethona. Przedsięwzięcie Mehmeda II ilustruje ważne dla nas $\mathrm{w}$ tym miejscu cechy osmańskiego systemu gospodarowania ziemią oraz przychodami z niej czerpanymi. Z punktu widzenia Plethona istotne byłyby tu następujące elementy: po pierwsze, osmańskie nadania wojskowe dotyczyły praw do dochodów a nie praw własnościowych ziemi; po drugie, możliwość korzystania $\mathrm{z}$ tych nadań była ściśle związana $\mathrm{z}$ działalnością (często militarna) na rzecz państwa. $Z$ tego punktu widzenia system timar staje się szczególnie interesujący. $W$ jego ramach zależność między służbą wojskową a dochodami staje się jeszcze ściślejsza, ponieważ istnieje możliwość weryfikacji zasadności przyznania praw majątkowych. Brak dziedziczności i swoista mobilność uważane są za główne cechy charakterystyczne tego systemu ${ }^{27}$.

Inspiracje osmańskie mogą dziwić u filozofa tak przywiązanego do helleńskiej tradycji. W tym wypadku należy jednak ograniczyć sceptycyzm. Pamiętajmy, że Plethon przebywał przez pewien czas na terytoriach kontrolowanych przez groźnego sąsiada. Gdzie dokładnie rezydował - w Prusie, w Adrianopolu $^{28}$, a może $\mathrm{w}$ innym centrum - to temat spekulacji. Jest też dla nas zagadką, na ile Plethon interesował się systemem podatkowym Osmanów podczas swojej wizyty. Skąpe informacje mówią, że studiował tam głównie nauki filozoficzne. Nie jest jednak wykluczone, że jego zainteresowania już wtedy wykraczały poza tę tematykę. Prawdopodobnie pierwszy osmański rejestr podatkowy powstał za czasów Bajezyda I (3 XII 1447 - 26 V 1512; sułtan od 1481), a więc w okresie, w którym Plethon przebywał na terytoriach osmańskich ${ }^{29}$.

Jeśli skupimy się na cechach ważnych dla Plethona, okaże się, że i w imperium osmańskim i $\mathrm{w}$ Bizancjum istnieją instytucje spełniające postawione przez niego warunki. Warto zwrócić uwagę na fakt, że również bizantyńska pronoia zawierała element warunkowości. Ten element zanikał z upływem $\mathrm{czasu}^{30}$. Postulaty Plethona można traktować jako nawoływanie do reformy

${ }^{25}$ Por. tamże, s. 114-117.

${ }^{26}$ Por. Özel, Limits of the Almighty, passim. Odnośnie rozwiązania pośredniego między nadaniami mülk i systemem timar por. M.L. Venzke, Aleppo's Mālikāne-Dīvānī System, „Journal of the American Oriental Society" 106 (1986) nr 3, 451-469.

${ }^{27}$ Por. İnalc1k, An Economic and Social History of the Ottoman Empire, s. 114-116.

${ }^{28}$ Por. И. Медведев, Мистра. Очерки истории и культуры поздневизантийского города, Ленинград 1973, 99; Woodhouse, George Gemistos Plethon, s. 26.

${ }^{29}$ Por. J. Shinder, Early Ottoman Administration in the Wilderness: Some Limits on Comparison, „Journal of Middle East Studies” 9 (1978) fasc. 4, 497-517.

${ }^{30}$ Interesująca w tym kontekście staje się teza o możliwym pochodzeniu osmańskiej instytucji 
w oparciu o tradycyjny system pronoi, nieobejmujący dziedziczności nadania, lub w oparciu o osmański system timar.

Reforma Mehmeda II jest dla nas interesująca jeszcze z innego powodu. Została ona w podobny sposób błędnie zinterpretowana, co koncepcje Plethona. We wcześniejszych badaniach określano reorganizację Mehmeda II jako reformę stosunków własności ziemi. Byłaby to próba zamachu na grupę właścicieli majątków ziemskich. Próba pozbawienia ich wpływów na losy państwa. W rzeczywistości była to reforma podatkowa ${ }^{31}$.

Reformy proponowane przez Plethona były z całą pewnością radykalne, ale radykalizmu doszukiwano się również w tych ich elementach, w których niekoniecznie można się go doszukać. Deklarację Plethona o tym, że ziemia powinna być do dyspozycji tego, kto jest w stanie ją uprawiać ${ }^{32}$ interpretowano jako postulat „zniesienia własności prywatnej” ${ }^{33}$. Na myśl przychodzą rozwiązania przypisywane spartańskiemu społeczeństwu czasów Likurga (IX/VIII w. prz. Chr.). Według przekazu Plutarcha (ok. 50 - ok. 125):

„Chcąc usunąć butę, zawiść, niegodziwość, przepych, a nawet jeszcze starsze od nich i poważniejsze choroby państwa: bogactwo i biedę, Likurg nakłonił współobywateli, aby całą ziemię oddali ogółowi dla ponownego rozdzielenia i rozpoczęli wspólne życie na zasadach całkowitej równości oraz posiadania jednakowych działek; mogli ze sobą rywalizować tylko w dzielności bojowej”34.

Z kolei wysokie wymagania moralne, jakie wysuwa w stosunku do swoich żołnierzy Platon (427-347 prz. Chr.), również mają przełożenie na sugerowany umiar w pożądaniu dóbr materialnych:

„Po pierwsze żaden z nich nie powinien mieć żadnego osobistego majątku, chyba że niezbędna konieczność. [...] A na utrzymanie, jakiego potrzebują zapaśnicy wojenni umiarkowani i odważni powinni od innych obywateli otrzymywać żołd według taksy. Tak wielki, żeby im nic z niego nie zostawało na następny rok, ani żeby im nie brakło" ${ }^{35}$.

Zauważmy jednak, że w systemie pronoia własność ziemi nie jest sprawą kluczową. Udostępnienie ziemi leżącej odłogiem osobom, które były w stanie ją zagospodarować mogło się odbywać w ramach istniejących w Bizancjum

timar właśnie od bizantyńskiej pronoia. Por. C. Cahen, Pre-Ottoman Turkey, New York 1968, 183183; Shinder, Early Ottoman Administration in the Wilderness, passim.

${ }^{31}$ Por. Özel, Limits of the Almighty, passim.

${ }^{32}$ Por. Georgius Gemistus Plethon, Ad regem Emmanuelem de rebus Peloponnesiacis Oratio I, ed. $\Lambda \alpha ́ \mu \pi \rho \circ \varsigma$, t. 3, s. 261, 4-7.

${ }^{33}$ Siniossoglou, Radical Platonism in Byzantium, s. 337, thum. własne.

${ }^{34}$ Plutarchus, Lycurgus 8, 3, w: tenże, Vitae parallelae, vol. 3, fasc. 2, ed. K. Ziegler, Lipsiae 1973, 12, 2-8, thum. K. Korus: Plutarch, Żywoty równoległe, t. 1, Warszawa 2004, 213.

${ }^{35}$ Plato, Res publica III 22, 416D-E, w: tenże, Dialogi, ed. K.F. Hermann, vol. 4, Lipsiae 1911, 102, tłum. W. Witwicki: Platon, Państwo, Warszawa 1994, 162. 
instytucji. Taki postulat nie oznacza koniecznie nawoływania do rewizji stosunków własnościowych w oparciu o wzorce z zamierzchłej przeszłości.

3. Helleński wizjoner. Odnosząc się do starożytnych inspiracji Plethona, Niketas Siniossoglou w swojej niezwykle cennej i przenikliwej pracy stwierdza, co następuje: ,[...] trzy źródła, które mogły mieć wpływ na Plethona to Państwo, Platona, Sparta i konstytucja Hippodamosa, którego myśl przekazał Arystoteles" $"$ ".

Jest to konstatacja do pewnego stopnia zbieżna $\mathrm{z}$ deklaracjami samego Plethona, który we wstępie do swoich Praw obiecuje przedstawić:

„Ustrój lakoński, z wykluczeniem wychowania nazbyt twardego i dla wielu nie do przyjęcia, natomiast z dodatkiem filozofii odnoszącej się zwłaszcza do rządzących, tego najlepszego z ustrojów platońskich" ${ }^{37}$.

Rzeczywiście, poglądy Hippodamosa (IV w. prz. Chr.), referowane przez Arystotelesa (384-322 prz. Chr.), noszą pewne znamiona podobieństwa do koncepcji Plethona:

„Przyjmował on dla swego państwa liczbę 10000 obywateli, podzielonych na trzy grupy: jedną z nich stanowili mianowicie - według niego - rzemieślnicy, drugą rolnicy, trzecią uzbrojeni wojownicy" ${ }^{\prime 38}$.

Hippodamos, podobnie do Plethona postulował podział społeczeństwa na trzy grupy, których rolą byłoby: dostarczanie towarów rzemieślniczych, produkcja żywności oraz obrona kraju. Na tym jednak podobieństwa się kończą. Starożytny myśliciel nie dość skrupulatnie przemyślał kwestię redystrybucji dóbr, tak ważną dla peloponeskiego polihistora. Plethon pewnie mógłby się podpisać pod Arystotelejską krytyką omawianej propozycji:

„Jeżeli zaś wojownicy sami będą uprawiać ziemię państwową, przeznaczoną na ich utrzymanie, to nie będą się niczym różnić od grupy rolników, czego przecież domaga się prawodawca. Jeśli jednak uprawą mają zająć się inni ludzie aniżeli rolnicy, gospodarujący na swoim, i wojownicy, to będzie to czwarta grupa w państwie, nie mająca żadnych praw politycznych, a więc pozostająca właściwie poza państwem"39.

Plethon bardzo starannie rozstrzygnął kwestię dochodów strażników swojego państwa. System podatkowy stanowił centrum jego koncepcji. Zastosowanie ustroju Hippodamosa potencjalnie groziło popadnięciem dokładnie

\footnotetext{
${ }^{36}$ Siniossoglou, Radical Platonism in Byzantium, s. 336, thum. własne.

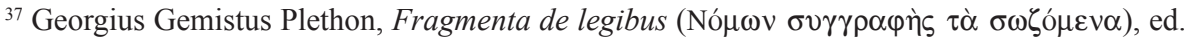
C. Alexandre: Pléthon, Traité des lois, Paris 1858, 2-3, tłum. własne.

${ }^{38}$ Aristoteles, Politica II 8, 1267 b 30-33, w: tenże, [Opera], ed. I. Bekker, vol. 2, Berolini 1831, 1267, thum. L. Piotrowicz: Arystoteles, Polityka, Warszawa 2004, 60.

${ }^{39}$ Tamże II 8, 1268 a 35-40, ed. Bekker, s. 1268, thum. Piotrowicz, s. 61.
} 
w takie kłopoty, jakich Plethon chciał uniknąć: żołnierze, zamiast zając się wojaczką, musieliby uprawiać rolę. Zagrażało to stabilności zarówno systemu obronnego, jak i fiskalnego.

Ustrój spartański z kolei w ogóle nie znajduje uznania opisującego go Arystotelesa: nadmierna tu rola kobiet w życiu publicznym, niewłaściwe stosunki własnościowe, patologiczna procedura wyboru władców. Próżno szukać inspiracji dla prawidłowo urządzonego państwa. Może w jednym punkcie ta propozycja ustrojowa mogłaby znaleźć uznanie Plethona:

,[...] cały system jego [Likurga] praw ma bowiem na względzie tylko jeden dział cnoty, a mianowicie zalety wojenne, bo te są użyteczne do panowania" ${ }^{40}$.

Reforma systemu zarządzania Peloponezem miała za cel usprawnienie obrony jednego z ostatnich zwartych terytoriów bizantyńskich. Jednostronność, która dla Arystotelesa była wada, dla Plethona mogła być zaletą. Mógł więc poszukiwać inspiracji $\mathrm{w}$ alternatywnym opisie ustroju spartańskiego - tym, który przekazuje Plutarch w żywocie Likurga. Paradoksalnie jednak wydaje się, że spartański ustrój w tym wydaniu mógł zainspirować Plethona raczej w kwestiach niezwiązanych z wojskowością, a z handlem. Likurg miał ograniczyć obieg pieniądza oraz produkcję rzemieślniczą. To postulaty bliskie Plethonowi. Co zaś się tyczy ogółu obywateli, a więc i żołnierzy, peloponeskiemu filozofowi z całą pewnością spodobał się pomysł przydzielenia mieszkańcom działek takiej wielkości, aby zapewnić produkcję pożywienia w ilości nie przesadnej, ale odpowiedniej, takiej, która

„[...] w zupełności wystarczy, by zachować tężyznę fizyczną oraz dobre zdrowie i nie potrzebować niczego więcej”41.

Poszukując istotniejszych elementów wspólnych, Christos Baloglu sugeruje, że stosunki łączące helotę i Spartanina są modelem dla propozycji Plethona, dotyczącej relacji między rolnikami a żołnierzami ${ }^{42}$. Istotnie, Plutarch deklaruje, że w Sparcie „to Heloci pracowali dla nich na roli, płacąc wyznaczony podatek"43.

Swoich chłopów Plethon konsekwentnie nazywa właśnie helotami. Zauważmy jednak, że heloci spartańscy pozostają poza obrębem społeczeństwa. Dla Plethona rolnicy są równoprawną grupą społeczną ${ }^{44}$.

${ }^{40}$ Tamże II 9, 1268 a 2-3, ed. Bekker, s. 1271, thum. Piotrowicz, s. 68.

${ }^{41}$ Plutarchus, Lycurgus 8, 8, ed. Ziegler, s. 12, 20-22, thum. Korus, s. 214.

${ }^{42}$ Por. Ch.P. Baloglu, The Institutions of Ancient Sparta in the Works of Plethon, w: Proceedings of the International Congress on Plethon and his Time (Mystras, 26-29 June 2002), Athens - Mystras 2003, 311-326.

${ }^{43}$ Plutarchus, Lycurgus 24, 2, ed. Ziegler, s. 37, 23-24, thum. Korus, s. 240.

${ }^{44}$ Por. Georgius Gemistus Plethon, Ad regem Emmanuelem de rebus Peloponnesiacis Oratio I, ed. $\Lambda \alpha ́ \mu \pi \rho \circ \varsigma$, t. 3, s. 256, 1-4. 
Zarówno propozycje Hippodamosa jak i model spartański wykazują jedynie powierzchowne podobieństwo do analizowanych przez nas propozycji ustrojowych. Pozostaje nam autorytet jednego z najważniejszych nauczycieli Plethona. Inspiracji platońskich można dopatrzyć się przede wszystkim $\mathrm{w}$ dwu podstawowych postulatach dotyczących proponowanej przez niego struktury wojskowej: w postulacie utworzenia grupy żołnierzy, ściśle odseparowanej od reszty społeczeństwa, oraz w postulacie powierzenia rządów w państwie tej samej grupie, która odpowiedzialna jest za jego obronę. F. Ma-

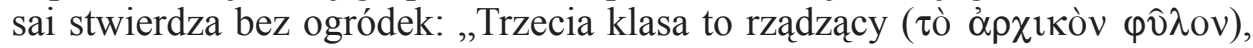
«strażnicy» Platona"45.

Jednak i tu pojawiają się pewne istotne różnice. Platoński podział społeczeństwa wynika z analizy natury ludzkiej - z przekonania, że każdy powinien zajmować się tym, w czym jest dobry, i tylko tym. Ustrój państwa powinien być dostosowany do możliwości składających się nań jednostek ${ }^{46}$. Podobny sposób rozumowania nakazuje dopuszczenie pewnych osób do sprawowania funkcji wojskowych, a izolowanie od nich innych:

„A czy rzemiosło wojenne nie jest najwięcej warte, jeżeli się je dobrze wykonywa? Czy ono takie łatwe, że i rolnik jakiś będzie zarazem dobrym żołnierzem i szewc, i pracujący w dowolnej innej umiejętności, a w warcaby dobrze grać albo w kości nie potrafi nikt, jeżeli się tym właśnie nie zajmie od dziecka, a tylko bawi się tym w wolnych chwilach"47.

Zawód żołnierza jest zawodem szczególnym, „najwięcej wartym”, a więc nie może wykonywać go byle kto:

„[...] u nas będzie to musiał być z natury filozof i pełny temperamentu, i szybki w biegu, i mocny każdy, kto by miał być doskonałym strażnikiem państwa $[\ldots]^{\prime \prime 48}$.

Kandydatów do tej zaszczytnej funkcji należy wybierać skrupulatnie już od młodzieńczych lat, a następnie poddawać ich metodycznemu procesowi wychowawczemu połączonemu z dalszą selekcją ${ }^{49}$. Przedsięwzięcie Platona ma na celu ustanowienie sprawiedliwego państwa. Jest to proces długotrwały ${ }^{50}$.

${ }^{45}$ Masai, Pléthon et le platonisme de Mistra, s. 74, thum. własne.

${ }^{46}$ Por. P. Coby, On Warriors \& Artisans: The Case for Moral Virtue in Platon's „Republic”, „Polity” 15 (1983) nr 4, 515-535; F.M. Cornford, Plato's Commonwealth, „Greece \& Rome” 4 (1935) nr 11, 92-108.

${ }^{47}$ Plato, Res publica II 14, 374C, ed. Hermann, s. 55, thum. Witwicki, s. 94.

${ }^{48}$ Tamże II 16, 376C, ed. Hermann, s. 57, tłum. Witwicki, s. 97-98.

${ }^{49}$ Por. C.D.C. Reeve, Philosopher-Kings: The Argument of Plato's Republic, Princeton 1988, 178-186.

${ }^{50}$ Por. Z. Planinc, Plato's Political Philosophy. Prudence in the „Republic” and the „Laws”, Columbia - London 1991, 144-151. 
Najlepszymi kandydatami na władców są filozofowie ${ }^{51}$. Dla Plethona bodźcem jest refleksja nad niewydolnością systemu podatkowego i obronnego. Celem jest natomiast zapewnienie obrony Peloponezowi i przetrwania państwu Paleologów ${ }^{52}$. Deklaruje co prawda, że należy „do obu z tych [grup przydzielić], każdego [według tego] raczej, [do jakiej] zdaje się być urodzony"53, ale nie jest to postulat kluczowy.

Dla Platona wojsko jest tylko środkiem do osiągnięcia wyższego celu. Dla Plethona jest niemal celem samym w sobie. Oczywiście nie należy zapominać o sytuacji, w jakiej znajdowało się Bizancjum w drugim dziesięcioleciu XV wieku. Dla Sokratesa (ok. 470-399 prz. Chr.), który w rzeczywistości referuje poglądy Platona, ewentualność prowadzenia wojny odnosiła się do sytuacji:

„[gdy] z ziemi sąsiadów coś nam odciąć wypadnie, jeżeli mamy jej mieć dość na pastwiska i pod pług [...]" ${ }^{\prime 54}$.

Dla Paleologów była to rzeczywistość powtarzających się najazdów i ciąłego zagrożenia. Trudno wymagać, aby w takiej sytuacji brano pod uwagę tak długofalowe środki, jak te, które proponuje Platon.

Istnieje opinia, że Platon stworzył Prawa jako bardziej realistyczną wersję ustroju zaproponowanego w Państwie ${ }^{55}$. Miałby to być wynik jego rozgoryczenia, kiedy zdał sobie sprawę, że nie jest możliwym znalezienie kandydatów na królów-filozofów, a przynajmniej nie tylu, ilu by potrzeba do stworzenia organizacji państwowej ${ }^{56}$. Plethon w ogóle nie mógł liczyć na możliwość dysponowania dostatecznym czasem dla przygotowania swoich reform. Ich wyniki potrzebne były natychmiast. Prawa więc raczej, a nie Państwo stanowiłyby bardziej użyteczny wzorzec. Problem w tym, że Prawa przekazują koncepcję jeszcze odleglejszą od Plethońskiej. Platon powtarza wymaganie bezinteresownej służby państwu ${ }^{57}$. Jednocześnie zmienia się kompozycja postulowanego społeczeństwa. Odrębna grupa strażników praktycznie przestaje istniec $^{58}$, natomiast rządy w państwie powierzono na wpół demokratycznie wybranej Radzie oraz Straży Nocnej. Relacja tej ostatniej oraz pozostałych

\footnotetext{
${ }^{51}$ Por. M. Schofield, Plato: Political Philosophy, Oxford 2006, 155-164.

${ }^{52}$ Por. Laiou, Economic Though and Ideology, s. 1139.

${ }^{53}$ Georgius Gemistus Plethon, Ad regem Emmanuelem de rebus Peloponnesiacis Oratio I, ed.

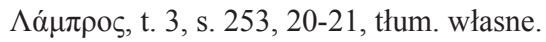

${ }^{54}$ Plato, Res publica II 14, 374D, ed. Hermann, s. 54, tłum. Witwicki, s. 93.

${ }^{55}$ Por. Ch. Bruell, On Plato's Political Philosophy, „The Review of Politics” 56 (1994) fasc. 2, 261-282, spec. 276-282.

${ }^{56}$ Por. E. Voegelin, The Collected Works of Eric Voegelin, vol. 16: Order and History, vol. 3: Plato and Aristotle, ed. D. Germino, Columbia 2000, 269-277.

${ }^{57}$ Por. Plato, Leges XII 7, 955C-D, w: tenże, Dialogi, ed. K.F. Hermann, vol. 5, Lipsiae 1920, 399, tłum. M. Maykowska: Platon, Prawa, Warszawa 1997, 496.

${ }^{58}$ Por. Voegelin, The Collected Works, s. 273.
} 
instytucji jest na tyle złożona ${ }^{59}$, że w niczym nie przypomina naiwnej prostoty propozycji Plethona.

Czy z powodu oczywistych różnic należy w ogóle odrzucić pogląd o inspiracjach platońskich Plethona? Naszym zdaniem nie. Trafnie, choć w sposób nieco krzywdzący ujął sprawę Joanis Mamalakis: „Nie powinniśmy zapominać, że [Plethon] zwraca się do młodego władcy, na którym próbuje wywrzeć wrażenie i którego próbuje zadziwić. Dlatego, oprócz innych środków, których używa jako uczony, musi również dowieść wartości swojej wiedzy i myśli filozoficznej, swego ducha. Dlatego przedstawia platońskie poglądy na temat wyodrębnienia trzech części społeczeństwa (Państwo) i o tym, że ustrój ma wpływ na powodzenie lub niepowodzenie państwa (Prawa, ks. IV)" ${ }^{\prime \prime 0}$.

Oczywiście bez względu na to, czy bierzemy pod uwagę korespondencję z młodszym o jakieś pół wieku Teodorem II, czy pisma adresowane do rówieśnika, Manuela II, Plethon nie musiał na żadnym z nich wywierać wrażenia. Jego reputacja była ustalona. Jednak reformy proponowane $\mathrm{w}$ analizowanych pismach były dość ryzykowne. Ich efektem byłoby znaczne zubożenie najbardziej wpływowych osób w państwie. Czy w takim wypadku nie warto użyć każdego dostępnego środka perswazji? Posłużmy się tu jeszcze jednym przykładem.

Plethon nawoływał warstwę rządzącą w swoim państwie do zaprzestania jakiejkolwiek działalności handlowej. Osoby, które nie podporządkowałyby się tym wymaganiom, miałyby tracić swoje miejsce wśród rządzącej elity ${ }^{61}$. Taki postulat można oczywiście traktować jako kolejne nawiązanie do państwa Platońskiego. Nie może ta sama jednostka wykonywać dobrze dwu zawodów. Jeśli preferuje działalność komercyjną, musi zrezygnować z rządzenia. Podobnie Likurg, w przekazie Plutarcha mieszkańcom Sparty

„Nie pozwolił w ogóle zajmować się rzemiosłem, nie mogli też gromadzić pieniędzy, bo to zawsze niesie ze sobą pełne trudu zaaferowanie, a ponadto nauczył ich nie tylko nie rywalizować w gromadzeniu bogactwa, ale też traktować je z pogardą"62.

Zwrócono uwagę na fakt, że podobne stanowisko zajmowali bizantyńscy teoretycy w XII wieku ${ }^{63}$. Postulat, który z dzisiejszej perspektywy może się nam jawić jako propozycja radykalna, wzorowana na teorii lub domniemanej

${ }^{59}$ Por. G. Klosko, The Nocturnal Council in Plato's „Laws”, „Political Studies” 36 (1988) 74-88.

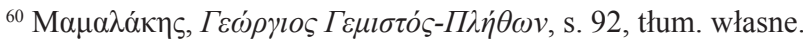

${ }^{61}$ Por. Georgius Gemistus Plethon, Ad principem Theodorum de rebus Peloponnesiacis Oratio II, ed. $\Lambda \alpha ́ \mu \pi \rho \rho$, t. 4, s. 131, 22 - 132, 4.

${ }^{62}$ Plutarchus, Lycurgus 24, 2, ed. Ziegler, s. 37, 19-23, thum. Korus, s. 240.

${ }^{63}$ Por. Laiou, Economic Though and Ideology, s. 1143. Odnośnie stosunku bizantyńskich uczo-

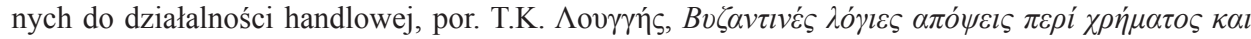

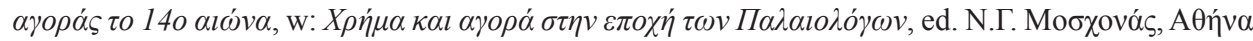
2003, 349-363. 
praktyce sprzed dziesiątek stuleci, może jednocześnie być interpretowany jako swoisty bizantyński konserwatyzm. Podobnie patrzeć można na ogólne założenia reformy organizacji wojskowej Peoloponezu. Przy całej swojej ekscentryczności propozycja Plethona była próbą powiązania przychodów czerpanych z ziemi z działalnością cywilną lub wojskową na rzecz państwa czyli z przywróceniem instytucji pronoi charakteru, jaki miała w czasach dla Bizancjum pomyślniejszych. Spodziewając się oporu wobec takiego kierunku działań Plethon uznał za stosowne poprzeć swe propozycje siłą starożytnego autorytetu.

Inspiracje starożytne pełnią w tekstach politycznych Plethona podwójną funkcję. Filozof używa starożytnych autorytetów jako argumentu przemawiającego za trafnością przyjętych przez siebie rozwiązań. $Z$ drugiej strony, jest to część szerszej strategii komunikacyjnej. Używając mocno archaizującego języka oraz starożytnego nazewnictwa, filozof stara się włączyć swoje propozycje ustrojowe w program odrodzenia kultury helleńskiej. Platon i Likurg to autorytety reprezentujące wartości, z którymi Plethon się utożsamiał. Warstwa praktyczna przekazu Plethona dotyczy natomiast głębokiej reformy instytucji bizantyńskich, a nie ich odrzucenia.

\section{MILITARY SYSTEM OF PELOPONNESE PROPOSED BY GEORGE GEMISTOS PLETHON}

\section{(Summary)}

The article summarises, analyses and develops the opinions conveyed by the secondary literature regarding the inspirations for the reorganisation of the military system of Peloponnese as proposed by George Gemistos Plethon. Three sources of inspiration taken into consideration are: the ancient one (Platonic theoretical framework and the Spartan society), the Byzantine one (the pronoia system) and the Ottoman one (the timar system). It seems that for Plethon the ancient component was more important in the symbolic sphere related to the Hellenic identity promoted by him. The core of the reform consists of the idea of binding the duties towards the state with the income derived from the land. The analogies are to be found among the institutions contemporary to Plethon.

Key words: Plethon, pronoia, timar, Platonic theoretical framework, Spartan society.

Słowa kluczowe: Plethon, pronoia, timar, filozofia polityczna Platona, społeczeństwo spartańskie. 
